MONITOROVANIE KRVNÉHO TLAKU U 14-15 ROČNÝCH DETÍ V OKRESE MARTIN

\title{
MONITORING THE BLOOD PRESSURE IN CHILDREN AT THE AGE OF 14-15 IN MARTIN
}

\section{Anna Ovšonková}

Ústav ošetrovatel'stva, Jesseniova lekárska fakulta v Martine, Univerzita Komenského v Bratislave

\section{Abstrakt}

V práci sme sa zamerali na meranie a hodnotenie krvného tlaku u detí vo veku 14-15 rokov podla Štvrtej správy Amerického Národného edukačného programu pre vysoký krvný tlak (NHBPEP) pracovnej skupiny pre deti a adolescentov z roku 2004 s cielom identifikovat jednotlivcov s rizikovými hodnotami krvného tlaku.

Na zber empirických údajov sme použili meranie fyziologických funkcií(krvný tlak, pulz) a antropometrické merania (výška, hmotnost').

Rizikové hodnoty systolického a diastolického krvného tlaku ( $\geq$ 90. percentil) hodnoteného podla Štvrtej správy NHBPEP malo 13 (13\%) chlapcov a rovnako 13 (13\%) dievčat. Rizikové hodnoty iba systolického krvného tlaku malo 18 (18 \%) chlapcov a 7 (7\%) dievčat a rizikové hodnoty iba diastolického krvného tlaku malo 10 (10\%) chlapcov a 5 (5\%) dievčat. Niektorí probandi dosiahli až hypertenzné hodnoty (> 95. percentil). Priemerné hodnoty krvného tlaku v sledovanom súbore boli vyššie ako priemerné hodnoty krvného tlaku v Štvrtej správe NHBPEP . 
Pravidelným rutinným meraním a správnym zhodnotením krvného tlaku môže sestra včas odhaliț deti s rizikovými hodnotami krvného tlaku.

\section{Abstract}

Our research was focused on taking and evaluating blood pressure in children at the age of 14-15 according to 4th Report of National High Blood Pressure Educational Programme (NHBPEP), the work group for children and adolescents by the year 2004 with the aim to identify the individuals with risk blood pressure values.

Risk values in both the systolic and diastolic blood pressure ( $\geq 90$.percentile) judged by 4th NHBPEP Report occurred in 13 (13\%) boys as well as in 13 (13\%) girls. Risk values in only systolic pressure occurred in 18 (18\%) boys and 7 (7\%) girls, risk values in only diastolic blood pressure occurred in 10 (10\%) boys and 5 (5\%) girls. In some respondents, no fewer than hypertension values were reached (> 95 . percentile). In our research, the average blood pressure values in boys and girls were confirmed to be higher in comparison with values stated in 4 th Report NHBPEP.

Through routine blood pressure taking and its subsequent correct judgement, a nurse can detect the children with risk blood pressure values soon enough.

\section{Klúčové slová}

krvný tlak, percentil, metodika merania krvného tlaku, rizikové hodnoty, hypertenzia, BMI 


\section{Key words}

blood pressure, percentile, method of blood pressure taking, risk values, hypertension, BMI

\section{Úvod}

Arteriálna hypertenzia je jedným z hlavných rizikových faktorov kardiovaskulárnych chorôb a zároveň je druhá najčastejšia forma kardiovaskulárneho ochorenia $v$ dospelom veku. Velký dôraz sa kladie na včasné podchytenie rizikových jednotlivcov v čo najskoršom období.

Na vzniku primárnej hypertenzie sa podielajú endogénne a exogénne rizikové faktory, medzi ktoré patrí genetická predispozícia, nadváha a obezita, nadmerný prívod soli, fyzická inaktivita, fajčenie, nadmerný príjem alkoholu a stres.

Hodnota krvného tlaku (TK) v detskom veku je za normálnych okolností počas rastu udržiavaná na rovnakom percentile. Na základe toho možno usudzovat', že dieța, ktoré má zvýšené hodnoty TK už $V$ detstve, si tento zvýšený TK prenesie aj do dospelosti. (Seeman et al., 2003, s. 567) Vyhladávanie pacientov s vysokým TK V období detstva a adolescencie, ich správna diagnostika a liečba, sú dôležité úlohy pri prevencii proti kardiovaskulárnym chorobám všeobecne. (Čižmárová, 2004, S. 297)

Štandardizovaná technika merania a hodnotenia TK je základným predpokladom pre správnu diagnostiku a liečbu hypertenzie. Aby sme sa vyhli nesprávnej interpretácii nameraných hodnôt TK, u detí je nutné používat percentilové hodnotenie a hodnoty posudzovat podla veku, pohlavia a výšky diet’at’a. Na Slovensku chýba databáza hodnôt TK u detí, a tak východiskom pre techniku merania a hodnotenia TK u detí sú závery Štvrtej 
správy NHBPEP z roku 2004 alebo predchádzajúce správy z roku 1996 a 1987, ktoré sú používané celosvetovo.

\section{Ciel práce}

Ciel’om práce bolo porovnat hodnoty TK namerané u detí vo veku 14-15 rokov s hodnotami uvádzanými v Štvrtej správe NHBPEP z roku 2004. Analyzovat priemerné hodnoty TK u detí vo vybranej vekovej skupine 14-15 rokov namerané na dvoch stretnutiach s odstupom 3 mesiacov a určit' skupinu rizikových probandov, ktorých hodnota TK bola rovná alebo presahovala 90. percentil. Poukázat na problematiku merania a hodnotenia TK $\mathrm{v}$ detskom veku.

\section{Súbor}

Oslovených bolo 500 študentov z 5 základných škôl a 8 roč. gymnázia v Martine. Do súboru boli zaradené deti, ktoré spín̆ali zaradovacie kritériá: vek diet’ata 14-15 rokov, informovaný súhlas rodiča, súhlas diet’at’a, účast’ na obidvoch meraniach (s odstupom 3 mesiacov). Výskumu sa zúčastnilo 100 chlapcov a 100 dievčat, pričom priemerný vek u chlapcov bol 14,2 rokov a u dievčat 14,4 roka.

\section{Metodika}

Na zber empirických údajov sme použili meranie.

\section{1. merania fyziologických funkcií}

Krvný tlak bol meraný podla odporúčaní Štvrtej správy NHBPEP z roku 2004. (The Fourth Report NHBPEP, 2004) Používaný bol ortutový sfygmomanometer, ktorého stupnica bola delená po 2 mmHg. Výber manžety závisel od obvodu ramena. TK bol meraný $2 \mathrm{x} \quad \mathrm{V} \quad 5$ minútových intervaloch $\mathrm{v}$ zvláštnej miestnosti po 
predchádzajúcom 10 - 15 min. upokojení, bol meraný v sede, na pravej hornej končatine. Za hodnotu systolického krvného tlaku (STK) bol považovaný prvý Korotkovov fenomén a za hodnotu diastolického krvného tlaku (DTK) piaty Korotkovov fenomén. Z nameraných hodnôt bol vypočítaný aritmetický priemer. Zo zistených údajov bola určená percentilová hodnota pre STK a DTK vo vzt’ahu k pohlaviu, veku a výškovému percentilu podla tabuliek Štvrtej správy. TK bol meraný $2 \mathrm{x}$ na dvoch stretnutiach s odstupom 3 mesiacov.

Získané hodnoty boli porovnané a hodnoty rovnajúce sa a presahujúce 90. percentil boli považované za rizikové. Rizikoví respondenti dostali odporučenie pre návštevu u praktického lekára pre deti a dorast alebo u detského kardiológa. Na obidvoch stretnutiach bol meraný aj pulz na artérii radiális.

\section{2. antropometrické meranie}

$\mathrm{Na}$ prvom stretnutí sme realizovali antropometrické merania. Merali sme telesnú výšku a hmotnost'. Na základe týchto údajov bol určený výškový percentil a vypočítaný body mass index (BMI). Na hodnotenie BMI sme použili Národné štandardy pre BMI. (Národné štandardy BMI, 2006)

\section{Výsledky}

Pri meraní a hodnotení TK V detskom veku je nutné brat do úvahy celkový vývin diețata a jeho antropometrické ukazovatele.(tab.1) 
Tab. 1 Hodnotenie antropometrických ukazovatelov u 14-15 ročných detí

\begin{tabular}{|l|l|l|l|l|l|l|}
\hline \multirow{2}{*}{ Premenná } & Pohlavie & Priemer & $\mathbf{N}$ & $\begin{array}{l}\text { Št. } \\
\text { odchýlka }\end{array}$ & Minimum & Maximum \\
\hline \hline \multirow{2}{*}{ Výška (cm) } & Chlapci & 171,70 & 100 & 7,67 & 156 & 191 \\
\cline { 2 - 7 } & Dievčatá & 164,61 & 100 & 6,84 & 137 & 177 \\
\hline \multirow{2}{*}{$\begin{array}{l}\text { Hmotnost' } \\
\text { BMI }\end{array}$} & Chlapci & 59,59 & 100 & 11,32 & 35,90 & 90,40 \\
\cline { 2 - 7 } & Dievčatá & 54,37 & 100 & 8,59 & 37 & 83 \\
\hline \hline \multirow{2}{*}{$\begin{array}{l}\text { Obvod } \\
\text { ramena } \\
(\mathbf{c m})\end{array}$} & Chlapci & 20,14 & 100 & 3,16 & 14,02 & 29,86 \\
\cline { 2 - 7 } & Dievčatáa & 20,02 & 100 & 2,63 & 15,19 & 28,72 \\
\cline { 2 - 7 } & Dievčatá & 23,94 & 100 & 2,12 & 19 & 29 \\
\hline
\end{tabular}

Priemerné hodnoty výšky u chlapcov aj u dievčat sa nachádzali medzi 50.-75. percentilom. Priemerná výška u chlapcov bola 171,7 cm a pohybovala sa v rozpätí od 156 až do $191 \mathrm{~cm}$. U dievčat bola priemerná výška $164,6 \mathrm{~cm}$ a pohybovala sa v rozpätí od 137 od $177 \mathrm{~cm}$.

V našom súbore bola priemerná hodnota BMI u chlapcov 20,14 a u dievčat 20,02. V pásme optimálnych hodnôt (25.-75. percentil) sa nachádzalo takmer $60 \%$ probandov (59 chlapcov a 62 dievčat), nad 90. percentilom $12 \%$ (3 chlapci a 8 dievčat) a nad 97. percentilom $14 \%$ ( 8 chlapcov a 5 dievčat) probandov.

Priemerný obvod ramena bol u chlapcov $25 \mathrm{~cm}$ a pohyboval sa od $13,5 \mathrm{~cm}$ do $32 \mathrm{~cm}$. U dievčat bol priemerný obvod ramena $24 \mathrm{~cm}$ a pohyboval sa od $19 \mathrm{~cm}$ do $29 \mathrm{~cm}$. Toto široké rozpätie v hodnotách si vyžadovalo použitie 2 typov manžiet $(9 \mathrm{~cm}$ a 12 $\mathrm{cm})$. 
Tab. 2 Pearsonove korelačné koeficienty TK (mmHg)

a antropometrických ukazovatelov a pulzu

\begin{tabular}{|l|l|l|l|l|}
\hline \multirow{2}{*}{ Ukazovatele } & \multicolumn{2}{|l|}{ Chlapci (n $=100)$} & \multicolumn{1}{l|}{ Dievčatá (n = 100) } \\
\cline { 2 - 5 } & STK & DTK & STK & DTK \\
\hline \hline Hmotnost́(kg) & 0,22 & $-0,14$ & 0,15 & $-0,05$ \\
\hline Výška (cm) & 0,20 & 0,01 & 0,14 & $-0,13$ \\
\hline BMI & 0,15 & $-0,18$ & 0,09 & 0,01 \\
\hline Obvod ramena & 0,15 & $-0,13$ & 0,11 & $-0,04$ \\
\hline Pulz & 0,20 & 0,33 & 0,11 & 0,25 \\
\hline
\end{tabular}

V sledovanom súbore sa u chlapcov potvrdila malá korelácia medzi hodnotami STK a hmotnostou, výškou, BMI, obvodom ramena a pulzom. Medzi DTK a pulzom sa potvrdila stredná korelácia, medzi DTK a výškou sa korelácia nepotvrdila. (tab. 2)

U dievčat sa potvrdila malá korelácia medzi STK a hmotnostou, výškou, obvodom ramena a pulzom. Medzi STK a BMI sa korelácia nepotvrdila. Medzi DTK a pulzom sa potvrdila malá korelácia, medzi DTK a BMI sa korelácia nepotvrdila. (tab. 2)

U chlapcov vo vzt’ahu k veku, pohlaviu a výške bola celková priemerná hodnota TK ( $\mathrm{z}$ obidvoch stretnutí) 122/73 mmHg. U dievčat vo vzt̉ahu $k$ veku, pohlaviu a výške bola celková priemerná hodnota TK ( $\mathrm{z}$ obidvoch stretnutí) 117/72 mmHg. Priemerné hodnoty STK a DTK sa nachádzali u chlapcov aj u dievčat $v$ pásme medzi 50.90. percentilom. Priemerné hodnoty TK u chlapcov aj u dievčat boli pri druhom stretnutí nižšie ako pri prvom stretnutí. Priemerné hodnoty krvných tlakov u chlapcov boli vyššie ako u dievčat.

U chlapcov medzi hodnotami pri prvom a druhom stretnutí bola pri STK zistená silná korelácia (Pearsonov koeficient pre STK $=0,64, \operatorname{DTK}=0,37)$. U dievčat medzi hodnotami STK a DTK pri 
prvom a druhom stretnutí bola zistená stredná korelácia (Pearsonov koeficient pre $\operatorname{STK}=0,32, \operatorname{DTK}=0,37$ ).

Za rizikovú skupinu sú považované osoby s hodnotami TK rovnými a nad 90. percentilom. V našej vzorke malo rizikové obidve hodnoty TK 13 (13\%) chlapcov a rovnako 13 (13\%) dievčat. Rizikové hodnoty iba STK malo 18 (18\%) chlapcov a 7 (7\%) dievčat. Rizikové hodnoty iba DTK malo 10 (10\%) chlapcov a 5 (5\%) dievčat. Niektorí probandi dosiahli až hypertenzné hodnoty STK a DTK (nad 95. percentil).

Porovnávanie počtov detí v jednotlivých percentilových pásmach ukázalo, že pri druhom stretnutí bol počet detí v rizikových pásmach hodnôt TK nižší ako pri prvom stretnutí.

Tab. 3 Porovnanie priemerných hodnôt TK $\mathrm{v}$ sledovanom súbore a $v$ 4. správe NHBPEP

\begin{tabular}{|l|l|l|l|l|l|}
\hline Vek & Pohlavie & $\begin{array}{l}\mathbf{l} \\
\text { stretnutie }\end{array}$ & $\begin{array}{l}\mathbf{2} \\
\text { stretnutie }\end{array}$ & Celkovo & $\begin{array}{l}\text {. Správa } \\
\text { NHBPEP }\end{array}$ \\
\hline \multirow{2}{*}{$\begin{array}{l}\mathbf{1 4} \\
\text { rokov }\end{array}$} & $\begin{array}{l}\text { Chlapci } \\
(\mathrm{n}=69)\end{array}$ & $123 / 74 \mathrm{mmHg}$ & $121 / 73 \mathrm{mmHg}$ & $122 / 73 \mathrm{mmHg}$ & $\begin{array}{l}111 / 63 \\
\mathrm{mmHg}\end{array}$ \\
\cline { 2 - 6 } & $\begin{array}{l}\text { Dievčatá } \\
(\mathrm{n}=63)\end{array}$ & $120 / 73 \mathrm{mmHg}$ & $117 / 71 \mathrm{mmHg}$ & $118 / 72 \mathrm{mmHg}$ & $\begin{array}{l}109 / 64 \\
\mathrm{mmHg}\end{array}$ \\
\hline $\begin{array}{l}\mathbf{1 5} \\
\text { rokov }\end{array}$ & $\begin{array}{l}\text { Chlapci } \\
(\mathrm{n}=31)\end{array}$ & $123 / 73 \mathrm{mmHg}$ & $122 / 72 \mathrm{mmHg}$ & $123 / 73 \mathrm{mmHg}$ & $\begin{array}{l}113 / 64 \\
\mathrm{mmHg}\end{array}$ \\
\cline { 2 - 7 } & $\begin{array}{l}\text { Dievčatá } \\
(\mathrm{n}=37)\end{array}$ & $117 / 73 \mathrm{mmHg}$ & $113 / 71 \mathrm{mmHg}$ & $115 / 72 \mathrm{mmHg}$ & $\begin{array}{l}110 / 65 \\
\mathrm{mmHg}\end{array}$ \\
\hline
\end{tabular}

Pri porovnávaní priemerných hodnôt TK V sledovanom súbore s hodnotami TK uvedenými v 4. správe NHBPEP sme zistili, že V 4. správe NHBPEP sú hodnoty TK nižšie u chlapcov aj u dievčat. (tab. 3) 


\section{Diskusia}

Krvný tlak je variabilná veličina, čo osobitne platí najmä v období adolescencie. Pri určovaní hodnoty TK je nutné brat do úvahy pohlavie, telesnú výšku, hmotnost' a dosiahnutý stupeň telesnej zrelosti. Medzi hodnotou TK a telesnou výškou je tesnejšia korelácia ako medzi TK a chronologickým vekom diețat’a. (Čižmárová, 2004, s. 298)

Definícia hypertenzie u detí a adolescentov je založená na normatívnej distribúcii TK $V$ súbore zdravých jednotlivcov s ohladom na pohlavie, vek, telesný rast a etnickú skladbu príslušnej populácie. Pre deti a dorast SR doteraz neexistuje relevantná databáza normálnych hodnôt TK a v praxi sa používajú tabulky a grafy NHBPEP. (Regecová et al., 2007, s. 26)

Kellerová, Regecová (2006, s. K/C 101) uvádzajú, že napriek tomu, že sa tabulky NHBPEP používajú celosvetovo, vrátane Slovenska, treba zvážit' ich určité obmedzenia a nejednoznačné definície. Tabulky z meraní zmiešanej populácie USA nevyhovujú detskej populácii Slovenska rozdielnost̉ou v etnickej a socioekonomickej skladbe, genetickej výbave, nutričných zvyklostiach, životnom štýle, v antropometrických ukazovateloch, vyššom výskyte obezity a pod.

$\mathrm{Na}$ Slovensku bola realizovaná multicentrická štúdia s cielom získat prehlad o súčasnom stave distribúcie hodnôt TK u detí a dorastu. Prvé výsledky ukazujú, že priemerné hodnoty a percentilové hodnoty TK V súbore slovenských detí sa pohybujú na úrovni percentilov detí z americkej populácie vyššieho vzrastu, v niektorých vekových skupinách boli až o 5-15 mmHg vyššie ako percentilové hodnoty stredne vysokých amerických detí.(Regecová et al., 2007, s. 26) Podobné zistenia sme získali aj v našom výskume, kde priemerné hodnoty 
TK u 14-15 ročných detí boli vyššie ako v 4. správe NHBPEP. Tým sa potvrdzuje nutnost vytvorenia databázy úrovní krvného tlaku z populácie slovenských detí.

Krvný tlak má tendenciu sledovat určité percentily v priebehu Času (v anglosaskej literatúre označené "tracking"). Tracking fenomén je kvantifikovaný koreláciou TK V rôznych Časových okamihoch. Z toho vyplýva pravdepodobnost', že určitý jednotlivec, ktorý je v detstve v hornom pásme distribúcie pre TK, sa bude nachádzat’ $V$ tomto pásme distribúcie aj v dospelosti. Len na základe uvedených vzṫahov nemožno jednoznačne predpokladat', ktoré deti budú mat' $\mathrm{V}$ dospelosti TK vysoký, ale det’om $v$ hornom pásme precentilov treba venovat' zvýšenú pozornost’. (Kellerová, 1996, s. 142) Aj ked sme si vedomí toho, že hodnoty TK sme sledovali krátke obdobie (3 mesiace), u chlapcov bola preukázaná silná korelácia a u dievčat stredná korelácia medzi hodnotami TK pri prvom a druhom stretnutí.

\section{Záver}

Meranie TK patrí medzi základné činnosti $v$ práci sestry a v mnohých prípadoch je to práve sestra, ktorá zachytí zvýšený TK, pretože väčšina pacientov nemá symptómy a sú identifikovaní len cez rutinné meranie TK. Spol'ahlivá a štandardizovaná technika merania TK je základným predpokladom pre správnu diagnostiku a liečbu hypertenzie u detí. Základom prevencie rozvoja hypertenzie je identifikácia chorých alebo rizikových osôb v čo najmladšom veku. Aktívne vyhladávanie rizikových osôb, ich d’alšie sledovanie a konzultovanie s kardiológom môže prispiet' k včasnej diagnostike a liečbe ochorenia. Úspešnost je podmienená dobrou spoluprácou medzi zdravotníckymi 
pracovníkmi, dobrou informovanostou verejnosti a aktivizáciou jej záujmu o vlastné zdravie.

\section{Podporené Grantom UK č.258/2006.}

\section{Zoznam bibliografických odkazov}

ČIŽMÁROVÁ, E. 2004. Osobitosti a špecifiká hypertenzie v detskom a dorastovom veku. Kardiológia. 2004, roč. 13, č. 5, s. 297-302. ISSN 1336-2429.

KELLEROVÁ, E. 1996. Vývin systémového krvného tlaku. In JAVORKA, K. et al. Klinická fyziológia pre pediatrov. Martin: Osveta, 1996. s. 122-148. ISBN 80-217-0512-4.

KELLEROVÁ, E., REGECOVÁ, V. 2006. Fyziologická variabilita krvného tlaku u detí. Kardiológia. 2006, roč. 15, Č. 4, K/C 97-106. ISSN 1336-2429.

Národné štandardy BMI, 2006 (National Reference Standards BMI. [online] [cit. 2007-10-08] Dostupné

<http://www.slovanet.net/uvzsr/news/narodne_standardy.html >.

REGECOVÁ, V. et al. 2007. Distribúcia hodnôt krvného tlaku detí a mladistvých na slovensku - multicentrická štúdia. Kardiológia. 2007, roč. 16, Suppl. 1, s. 26. ISSN 1336-2429.

SEEMAN, T. et al. 2003. Arteriální hypertenze v dětském věku. Česko-slovenská pediatrie. 2003, roč. 58, č. 9, s. 566-578. ISSN $0069-2328$.

The Fourth Report on the Diagnosis, Evaluation and Treatment of High Blood Pressure in Children and Adolescents. National High Blood Pressure Education Program Working Group on High Blood Pressure in Children and Adolescents(NHBPEP). 2004. Pediatrics. 2004, roč. 114, Č. 2, s. 555-576. ISSN 1098-4275. 


\section{Kontakt na autora}

Mgr. Anna Ovšonková, PhD.

Ústav ošetrovatel'stva JLF UK Martin

Malá hora 5

Sk-036 32 Martin

ovsonkova@jfmed.uniba.sk 